\title{
RECENT ENGAGEMENTS WITH ADAM SMITH AND THE
}

\section{SCOTTISH ENLIGHTENMENT}

BY

\author{
MARIA PIA PAGANELLI
}

CHOPE WORKING PAPER NO. 2015-06

JUNE 2015

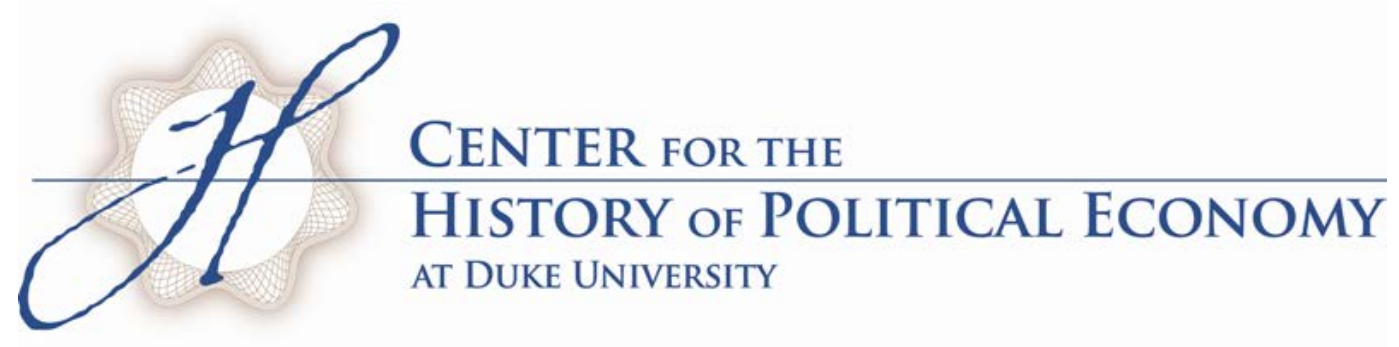




\title{
Recent Engagements with Adam Smith and the Scottish Enlightenment Maria Pia Paganelli
}

Trinity University

mpaganel@,trinity.edu

Forthcoming, History of Political Economy, 2015

\begin{abstract}
Recent literature on Adam Smith and other $18^{\text {th }}$ Scottish thinkers shows an engaged conversation between the Scots and today's scholars in the sciences that deal with humans-social sciences, humanities, as well as neuroscience and evolutionary psychology.

We share with the $18^{\text {th }}$ century Scots preoccupations about understanding human beings, human nature, sociability, moral development, our ability to understand nature and its possible creator, and about the possibilities to use our knowledge to improve our surrounding and standards of living. As our disciplines evolve, the studies of Smith and Scottish Enlightenment evolve with them. Smith and the Scots remain our interlocutors.
\end{abstract}

Keywords: adam smith, david hume, scottish enlightenment, recent literature

JLE: A1; A12; A13; A14; B1; B3; B30; B31; B4; B40; B41; C9; C90 
Forthcoming, History of Political Economy, 2015

\section{Recent Engagements with Adam Smith and the Scottish Enlightenment ${ }^{1}$}

Maria Pia Paganelli

David Levy once told me: “Adam Smith is still our colleague. He's not in the office but he's down the hall." Recent literature on Adam Smith and the Scottish Enlightenment shows Levy right.

At the time of writing, searching Econlit peer review journal articles for "Adam Smith" in the abstract gives 480 results since year 2000. Opening the search to Proquest gives 1870 results since 2000 (see Appendix 2 to get a rough sense of the size of recent literature). We still pose questions to Adam Smith. And he still answers, even if both the questions and the answers change with time. (For previous survey of literature on Smith see, for example, Tribe (1999), Brown (1997), Recktenwald (1978).) The scholarly approach may be Skinnerian, non-Skinnerian, or postSkinnerian, to adopt Lisa Herzog's language (2013), meaning that the answers we receive may derive from a historical reconstruction of the context, from a lack of attention to the context, or from something in between. Yet, just as Adam Smith engaged in conversations with other Scottish literati at his time and with ancient philosophers alike (Montes 2008a), he converses with us today.

Today, not unlike in the $18^{\text {th }}$ century, Adam Smith and his fellow-Scots talk not just to economists but to scholars of several disciplines (even if today scholars of different disciplines may or may not talk to each other as much). What we see today is a flourishing of scholarship on Smith and the Scottish Enlightenment in the sciences that deal with humans-social sciences, humanities, as well as neuroscience and evolutionary psychology.

\footnotetext{
${ }^{1}$ This literature review was commissioned by HOPE. Thanks to the Center for the History of Political Economy at Duke University and Trinity University for supporting this research. Thanks to the participants of the 2014 History of Political Economy Workshop for feedback and encouragement, in particular Roy Weintraub, Kevin Hoover, Craufurd Goodwin, Paul Dudenhefer, Leonidas Montes, and Reinhard Schumacher. Thanks also to Christopher Berry, Mauricio Couthino, Tyler Cowen, Jerry Evensky, David Levy, Steve Medema, Michael Munger, Craig Smith, and Vernon Smith.
} 
Recent literature on Adam Smith and the Scottish Enlightenment gives us a picture of Smith and the Scottish Enlightenment in whom we share preoccupations, elaborated in what follows, about understanding human beings, human nature, sociability, moral development, our ability to understand nature and its possible creator, and possibilities to use our knowledge to improve our surrounding and standards of living.

The picture I present here draws on a necessarily small sample of articles and books from different disciplines on Adam Smith and the Scottish Enlightenment. It cannot possibly be a complete one, but it will give a sense of what I see as some of the relevant themes that are being discussed in the literature. These themes are relevant themes in economics too, but it is impossible for me here to cover also the main economic literature. I limit myself to only the literature on Smith and the Scottish Enlightenment. Also, in this review the absence of references to Italian, French, Spanish, Portuguese, and Japanese scholarship is not an indication of lack of scholarship in these countries. On the contrary: Stefano Fiori, Sergio Cremaschi, Benoit Walraevens, Laurie Breban, Maria Alejandra Carrasco, Jimena Hurtado, Hugo da Gama, Mauricio Coutinho, Ryu Susato, Naohito Mori, Shinya Kawawaki, are just some of the many impressive scholars who have made important contributions to scholarship on Smith and the Scottish Enlightenment in languages other than English.

\section{What is the Scottish Enlightenment?}

The Scottish Enlightenment generally refers to the intellectual phenomenon of $18^{\text {th }}$ century Scotland.

In economics, the Enlightened Scots tend to live "in the shadow of Adam Smith," to use the suggestive title of the well documented book by Donald Rutherford (2012) on the wealth of economists in the $18^{\text {th }}$ century Scotland who tend to be overshadowed by the giant figure of Smith. But the crowd of geniuses who populated Scotland in the $18^{\text {th }}$ century, to paraphrase another recent suggestive title (Buchan 2003), include not just economists/philosophers such as Adam Smith (1723-1790) and David Hume (1711-1776), but also geologists, chemists, botanists, astronomers, poets, painters, clergymen, lawyers, noblemen, inventors. (For a sample of Scottish literati and their interests, see Appendix 1.) It is telling that Adam Smith's executors were a chemist, Joseph Black, and a geologist, James Hutton. 
The boundaries of Scotland and of $18^{\text {th }}$ century are permeable, so some non-Scots, such as the "never to be forgotten" Francis Hutcheson (1694-1746), an Irish-born philosopher, is counted as Scot, while Sir James Steuart (1712-1780), a Scot-born economist, is seldom counted in the troupe of Scottish literati. Montesquieu (1689-1755), on the other hand, despite being French and having no explicit connection with Scotland, is often bundled in the Scottish group.

The Scottishness of the Scottish Enlightenment is also not without controversies: Alexander Dow and Sheila Dow (2006) see the Scottish Enlightenment as a uniquely Scottish product; Alexander Broadie (2012) highlights Scotland's old and deep connections with France; and Aaron Garret and James Harris (Forthcoming) raise some questions about the Scottishness of "North Britain" instead.

Enlightenment for the Scots meant both independent thinking and sociality (Broadie [2007] 2011). What made the Enlightened enlightened was that the literati tried to understand the world around them without being deferential to authority, whether that of the church or of ancient texts. In addition to rejecting authority as a source of knowledge and seeking testable and experimental knowledge instead, the enlightened Scots believed in the power of sharing ideas with others: "It is one thing to think for yourself, another to think by yourself, and the enlightened ones were not much given to thinking by themselves. On the contrary, thinking was regarded as essentially a social activity. People thought with each other, that is, they shared their thoughts" (Broadie [2007] 2011, 20). “Think for yourself, but not by yourself” are characteristics with which we can easily relate today as well.

This large crowd of literati was closely bound together by family relations, teacher-student relations, and bonds of friendship. They would interact regularly not just in the three major universities of Scotland (Glasgow, Edinburgh, and Aberdeen), but also and especially in intellectual clubs and societies, such as the Rankenian Club, the Literary Society of Glasgow, the Aberdeen's Philosophical Society, the Select Society, the Poker Club, the Oyster Club, and the Philosophical Society of Edinburgh which eventually turned into the Royal Society of Edinburgh, among the most famous ones. In the regular meetings of these clubs and societies, their participants would discuss and debate topics ranging from moral philosophy, the economy, commerce, the military, rhetoric, theology, law, literature, fine arts, sociology, classics, mathematics, astronomy, chemistry, geology, physics, medicine, architecture, mechanics, logic...you name it. They were interested in learning, understanding, and knowledge in all its different forms (for a sense of the breath of the interests of 
the Scottish literati see Broadie 2006; Haakonssen 2006; Montes and Schliesser 2006; Norton 2009; Berry, Paganelli, and Smith 2013; see also Schliesser 2014).

The sociability and the sharing of ideas, the breadth and diversity of interests, ranging from painting to astronomy, not just of an individual but of the intellectual circles within which an individual would move is a recurrent theme in Ian Ross's ([1995] 2010) and in Nicholas Phillipson's (2010) biographies of Adam Smith as well as in James Harris's intellectual biography of David Hume (Forthcoming). With their breadth of interactions among the different branches of knowledge, the Scottish natural scientists are also, in David Wilson (2009)'s portrayal, genuine philosophers, lovers of knowledge, knowledge that includes the heavens as well as the soul. Just as Adam Smith was versed in astronomy and mathematics, mathematicians and astronomers were versed in law and moral philosophy. In this sense, Shinichi Nagao (2007), using astronomy and morality, makes a much cleaner argument than Jack Weinstein's (2013) convoluted one, based on morality alone, about the acceptance of pluralism in Smith and the Scots. Nagao shows with texts that "in the 18th century the cosmology of modern astronomy made 'plurality' mean the existence of other ecosystems on other planets in the universe. [...] [P]lurality is taken for granted" (Nagao 2007, 22).

\section{"Think for yourself." Science of man-history and the lab}

The ability to converse across disciplines and across time may be due, in part, to the generally common method of enquiry — the experimental method—and the common object of enquiry even if in different forms — nature. Newtonianism spread almost immediately and very quickly in Scotland's universities and intellectual circles (Montes 2008b), and its experimental method of enquiry with it. Man is part of nature just as the planets in the sky are. A method similar to the one used to study the sky can be used to study the rest of nature - men included. George Turnbull ([1740] 2005) claims that "we must enquire into moral phenomena, in the same manner as we do into physical one." (p. 56). The subtitle of Hume's Treatise is “introduce the experimental method of reasoning into moral subjects." What David Hume calls the "science of man," Adam Smith calls the "science of human nature" (Berry 2012). Man becomes the proper object of study by natural sciences. And the empirical and scientific investigation of human beings tries to yield deeper understanding of human nature, institutions, politics, religion, law, and the economy. 
In $18^{\text {th }}$ century Scotland, history became the laboratory where the Scottish literati used their empirical method. Informed by experience, we may observe similar reactions in similar circumstances. The more observations we have, the more observations from different times and from different places we have, the more consistent the regularities, the better off we are in formulating laws concerning human nature. "History teaches us of the nature of people in the more or less distant past. The study of history is a way of, so to say, extending our powers of observation $[\ldots][\mathrm{H}]$ istory thus contribute to the scientific account of human nature by massively extending our otherwise very limited observational data base” (Broadie [2007] 2011, 55). Adam Smith's writing blooms with historical examples. In his library we can count a large collection of history books (Mizuta 2000). The number and popularity of histories multiplied: David Hume's History of England, and William Robertson's The History of Scotland, The History of the Reign of Charles $V$, The History of America were all best-sellers.

Today, we have not just history but also laboratories with human subjects. So we find Adam Smith and the other Scots not just down the hall, but also in our labs: Tayor Jaworski, Vernon Smith and Bart Wilson (2010) are able to discover and teach the Scottish Enlightenment in the lab.

Today's experimental results, in part, forced economists to question the validity of the assumption that self-interest is the only motivation of bomo economicus and the relevance of the analysis of homo economicus' behavior. Richard Wagner (2014) and Vernon Smith (2013b) share concerns that the marginal revolution in economics has been "more negative than positive [...] because it led to the replacement of economics as social theory with economics as a theory of rational choice (Wagner 2010)" (Wagner 2014, p. 16; see also Backhouse and Medema 2009a; Backhouse and Medema 2009b). Similarly, Sheila Dow (2009) speculates that interpretations of the Scots, Smith in particular, as precursors of general equilibrium models attribute the Cartesian method to them. But Dow argues that Smith advocated the experimental method and not Cartesianism (cf. Amos Witztum (e.g. 2010), Elias Khalil (e.g. 2010), or even Nava Ashraf, Colin F. Camerer, and George Loewenstein (2005). See also Reinhard Schumacher (2012)).

The Scots identify a variety of motivational forces, including instincts, passions, emotions, feelings, which make formal modeling more complicated, but more realistic. As Jonathan Wight (2009) suggests: "If running a complex organization can be equated to sailing an ocean vessel, standard economic models rely only on one motivating force - the wind of calculated self-interest to fill the sail. However, Smith's concern for instincts and affections offers a complementary 
understanding of deeper hidden currents and tides that also move ships" (p. 109. On Hume's analysis of complex emotions and recent results in cognitive science, see Mark Collier (2011)).

The Scots in the 18th century, and Vernon Smith in particular today, lean more toward the idea of studying conduct, rather than behavior (V. Smith 2013b). Behavior implies a sort of mechanical response to specific incentives, and can be limiting. Conduct implies an understanding of the difference circumstances and different motivations in which an action takes place, so that the same set of incentives would generate different responses depending on the understanding of the context in which the incentives are set (V. Smith and Wilson 2014). The idea of conduct implies an idea of judgment, and an idea of judgment which is dependent on the perception of the context and intentions in which it is generated. Context matters because context helps us understand the intentions of others to judge the praiseworthiness of one's actions.

Perception and understanding of the environment in which an individual makes a choice is a fertile ground in which the laboratory joins Adam Smith and his countrymen (Wilson 2009) in terms of both the studying of systematic perception biases and the neurological way in which we are able to recognize the behavior of others.

To analyze moral conduct, the Scots generally prefer inductive models, proceeding from unconscious instincts and experiences, rather than postulating that good moral rules are the result of rational deduction. Adam Smith and David Hume believed that we understand others by imagining ourselves in their position and seeing how we would react under those circumstances. We judge if their conduct would correspond to ours. If they behave as we would, we approve of them. If they do not, we disapprove of them. Our reactions are a mixture of an automatic physical reaction (Humean sympathy) and an unconscious reasoning of the appropriateness of the reaction (Smithian sympathy). The discovery of mirror-neurons in mammals and primates, including humans (e.g. Iacoboni 2008), gives a biological foundations to the 18th century Scottish observations (Collier 2010; Paganelli 2011; Khalil 2011; Kiesling 2012).

Understanding the appropriateness of our own conduct follows a similar mechanism, especially for Adam Smith. We imagine ourselves being seen by someone else, unrelated to us, and our conduct being judged impartially by this spectator. James Konow (2012) highlights how similar Adam Smith's impartial spectator is to today's empirical and experimental methods that elicit thirdparty moral judgment. Paul Gabrinetti and Şule Özler (2014) and Özler and Gabrinetti 
(forthcoming) show how the impartial spectator resembles the Freudian super-ego function of morality in generating psychological defenses such as virtue, propriety, merit, duty that allow us to build a known world. The superego develops, in the same manner as the virtuous person in Smith's Theory of Moral Sentiments, through observation and mirroring others (see also Raphael 2007).

But the process of moral development is not automatic because our perception of ourselves and our surrounding may be biased by our limited vision. We need to learn how to perceive moral and physical distances alike. The agent's experiences may also limit the imagination of the spectator (Weinstein 2006). Our internal spectator is not therefore naturally unbiased and impartial: the tendency for self-deception tints our moral judgments about our own behavior (Khalil 2009), so much so that Samuel Fleischacker (2011a) sees self-deception as critical to understanding Smith's moral philosophy as a whole. We have to overcome the powerful forces of self-deceit, which for Smith are "the source of half the disorders of human life" (TMS III.4.6). James Konow (2000) suggests Smith's estimate might be conservative: even under sterile laboratory conditions, which are least conducive to self-deception, almost two-thirds of unfairness has been traced to such a bias (in Konow 2012). The problem may be exacerbated, as Warren Samuels (2007) implies, by our desire to "allay [the] tumult of the imagination" caused by events which we cannot explain: we "smooth the imagination" with connections (beliefs), independently of their truth (see also: Schliesser 2013).

\section{“Think with Others.” Sociability, race, gender, inequality, and morality of markets.}

How could we try at least partially to overcome our biases? Smith suggests a possible answer in the subtitle to the Theory of Moral Sentiments, added to its fourth edition: 'An essay towards an analysis of the principles by which men naturally judge concerning the conduct and character, first of their neighbors, and afterwards of themselves'. Our neighbors, the people around us, are, therefore, our first step in the development of our moral character (Paganelli 2010). Moral learning takes place thanks to the observation and imitation of others, through informal and unconscious learning, rather than through formal education (Wight 2009).

The Scots' emphasis on the importance of social interactions in the development of one's moral character, in the development of one's self, is characteristic of their thought. It is important also for us today. And it is easy to recognize in the questions commonly asked today --ranging from race to 
gender to income inequality, and to morality of markets - the same kinds of social and moral questions addressed by the Scots.

For the Scots, moral character develops in large part through the interactions with others. Reading, for example, for the Scots, is a social activity: it raises the question of how to read others. "The solitariness of sentimental novel reading was a major source of disquietude for moralists who believed that character was social" (Ahnert and Manning 2011, p. 19). Rhetoric is also an important instrument for social activities linked to moral development: our ability to "see just how our interests are interrelated with the interests of others" emerges "through an element of rhetorical practice itself: the need to adapt discourse appropriately to an audience” (McKenna 2006, p. 132). Communication, which rests on social convention, is an integral part of the Scots' theory of knowledge (Dow 2009).

Character is therefore a reflection of sociability and of society, as sociability and society are essential in the formation of character. An individual character is formed through the mirror of society, it is a product of society, and therefore the appropriateness of its characteristics may change with different social environments (e.g. Witztum 2005; Forman-Barzilai 2010; Fleischacker 2011b). But that character may change, does not imply that human nature itself is thought to change. With the idea of developing a science of man, or science of human nature, the Scots imply that human nature has laws, similar to physical nature, which can be discovered through observation: human nature itself is fixed (Evensky 2005; cf. Schliesser 2011) while character changes.

Yet, some differences are such as to question how many natures of man are present in nature. In his 1758-59 edition of Sistema Naturae (1735), the Swedish naturalist Carl Linneaus, while placing and classifying man in the natural system together with flora and fauna, divided man into bomo sapiens (coining the term) and troglodytes, placing man in the class of mammal and in the order of primates. Humankind was classified in four varieties, depending on his physical and moral characteristics: American, European, Asiatic, and African. These classifications, Silvia Sebastiani (2013) claims, opened the door to two ways of classification of humankind: monogenism and polygenism. Monogenism adopts the belief that every human group may derive from a single original stock. Polygenism explains human differences in terms of development from different progenitors. Montesquieu, Adam Smith, John Millar, Thomas Reid, James Beattie, and the group associated with the Wise Club of Aberdeen, seem to imply monogenism, while David Hume, Lord Kames, and William Robertson seem to imply polygenism, even if not without controversy (Sebastiani 2013). 
Regardless of whether human nature has different varieties, diversity of human character is a product of history. For the Scots, moral character, being a reflection of sociability, displays different characteristics in different environments (e.g. Berry 2010). In different stages of developmenthunter-gathering, pastoral, agricultural, and commercial—we observe and appreciate different virtues. Ancient Greece valued public virtues. Agricultural societies value stability and "masculine" virtues. The enlargement of society which commerce brings about implies increasing interactions with others, and with the other sex as well, which for most Scots allows people to be more sociable and more likely to develop sociable virtues (Hanley 2009). The Scots perceive the historical development as a process of civilization and feminization. Civil is in contrast to rude, as opposed to, say, Rousseau who would contrast civil with natural. The rudeness of the savage hunter-gatherer and barbaric nomadic shepherd is contrasted to the civilized agricultural and refined commercial society. Societies develop from rude savagery and barbarism, from masculine stages, where aggression, strength, and courage are valued, to more civil and feminine stages, where sociability, kindness, and desire to emulate are valued-to a world of conversation and commerce (Sebastiani 2013).

If, however, feminization slips into effeminacy, the development of society is perceived as dangerous and reproachable. Commercial societies, more than any other kinds of society, may lead to effeminacy, potentially distracting individual from the public sphere and weakening the traditional masculine virtues (Montes 2004). Adam Ferguson and Robert Wallace in particular, and in part also Adam Smith, see that the cost of the increased sociability is a decrease in martial spirit which could become a problem if the country needs to be defended. Fredrik Jonsson (2013) claims that the agricultural improvements in the Highlands (and the promotion of gardening) were meant to promote agricultural values, to counter the commercial laxity, and therefore to use the Highlands of Scotland as an incubator and reservoir of soldiers. James Macpherson's "translation", of Ossian's poetry between 1760 and 1763 solidified the ideals of traditional agricultural values of sobriety and martial spirit of the highlanders. The Caledonians become an idealized type that is able to combine the politeness and civility of a commercial society, in which there is no slavery and women are treated with respect and gallantry, with agricultural values (Sebastiani 2013).

The betterment in material conditions in commercial societies may also come at the expense of individual happiness (see also Peach 2014; Rasmussen 2006), yet the Scots generally tend to rebut

\footnotetext{
${ }^{2}$ Macpherson claimed to have collected oral Gaelic stories of ancient origins and then translated for publication. Yet, many doubted the authenticity of Macpherson's account, attributing the entirety of the poems to him.
} 
condemnations of commercial societies on the ground that commercial societies bring about the "two greatest blessings that man can possess" - "opulence and freedom" (LJ p.185)—not just for a few but for all. Michael Perelman (2011) disagrees, as he does not see Smith's view of commercial society as favoring all workers, especially not the poor ones.

Adam Smith, though, suggests that economic growth brings about higher wages for all (Waterman 2014; Aspromourgos 2010; on the differences between Smith's high wages and Malthus low wages see Waterman 2012). If wages do not rise, it is because special interests impose limits on maximum wages, which Smith strongly opposes, promoting generous compensations for poor workers instead (Martin Forthcoming). Maximum wages were based on the assumption that poor people are lazy and would stop working if wages rose. Smith argues instead that the assumption is incorrect because when poor workers "are liberally paid by the piece, are very apt to overwork themselves and to ruin their health and constitution in a few years" (WN p. 83). Using crosscountry European data, Keith Bender, Colin Green, and John Heywood (2012) show that, today as Smith claims for his time, there is a strong link between workplace injury and piece rates.

The attention paid to the poor is an unresolved debate in the literature: does Smith support redistribution to the poor or not? And, if he does, does he base it on rights of necessity and subsistence or on other grounds? No decisive answer is yet offered (Witztum and Young 2006; Salter 2012; Witztum 2013; see also Sen 2010).

If "the silent revolution of commerce" brings about "opulence" for all, most, or few, depending on who is reading the texts, it also brings about "freedom," according to Smith. And opulence and freedom are related.

The freedom that commerce brings about is a freedom that generally (but not always) eventually brings about the legal abolition of slavery-John Millar is among the most adamant among the Scots about this (Garrett 2006). Commerce also breaks the potentially tyrannical feudal bonds of dependency between servants and landlords (Paganelli 2013; for a psycoanalytican interpretation of Smith and dependency see Özler 2012). But the freedom that commerce brings about is also, and in particular, related to the fact that "commerce and manufactures gradually introduced order and good government, and with them, the liberty and security of individuals, among the inhabitants of the country, who had before lived almost in a continual state of war with their neighbours, and of servile dependency upon their superiors. This, though it has been the least observed, is by far the most 
important of all their effects. Mr. Hume is the only writer who, so far as I know, has hitherto taken notice of it" (WN III.iv.4, p.412).

There is also a third blessing that commerce brings about: habitual interactions with others, with non-kin and strangers in particular. For Smith, interacting with strangers helps us internalize rules of just conduct which makes us behave in a praiseworthy way and not behave in a blameworthy way even in the absence of a potential external enforcer of the rule of conduct (Paganelli 2010). Herbert Gintis and his coeditors (2005), through a set of experiments, see Smith's view of accumulation of moral capital as deriving from a natural predisposition to cooperate and trust others (cf. Smith 2013b; Smith 2008), a foundational feature in the evolution of complex societies. Paul Zak (2008) shows the positive effects on economic growth that moral capital may have, as well as its biological foundation (Zak 2012).

\section{Think to Improve: From Banks to Rhubarbs.}

The silent revolution of commerce, unintentionally and gradually, brings about several different kinds of improvements in human life. The understanding of the nature and the causes of these improvements may help us prevent their halting or their reversal, or in some cases even promote improvements. The science of man generates knowledge which could be used to improve human conditions. For example, this knowledge could be used to develop and implement new discoveries ranging from the extension of credit and banking to attempts to naturalize new plants in the countryside of Scotland. Economic development, the role of money and banking in the economy, and the relationship between men and their natural environment are common preoccupations of both today and $18^{\text {th }}$ century Scotland. They are reflected in recent literature on Smith and the Scottish enlightenment as well.

The silent revolution of commerce brings about good governance, Adam Smith tells us, which means it allows us to enjoy freedom under the rule of law. The advent of commerce implies an increasing process of abstraction which allows us to cope with and develop increasing complexity of social interactions and institutions. Individuals go from relying on personal rule of the tribal chief or local landlord to relying on an impersonal rule of law, for example, and contracts go from concrete barters to abstract letters of credit (Berry 2010; Berry 2013a). 
A place where one can see improvement is economic growth. For the Scots, economic growth is not just an accumulation of capital, increased division of labor, and possibly increasing returns to scale (for an overview of the state of economic understanding see Aspromourgos 2009; Young 2009). Economic growth is also a theory of social development, a history of civilization. A society is characterized not just by its material conditions and material incentives but also and in particular by its moral and psychological conditions and incentives.

For most Scots the theory of development is a stadial theory. Societies can be divided into four stages, each with its material, legal, political, social, and moral characteristics (on the difference among the Scots regarding stadial theories see Berry 2013b). Hunter-gatherers are "savages", with little property and little government. Women are subjected to men, there is slavery, and age and physical strength are marks of distinction. Shepherds are "barbarians" who begin to recognize property, but only in a limited way. Tribal chiefs rule with personal power and justice is generally arbitrary. With agricultural societies there is the development of property in land and chivalry which culminates with the refined and polite commercial societies. Here we see fully developed courts and legal systems, and evolved forms of government which rely on impersonal rule of law. Opulence is inexorably linked with good governance, the presence of the rule of law and of a good administration of justice.

This analysis of economic development offers inspiration and frustration today. The focus on institutions can be seen as parallel to Douglas North's (Kim 2014) and the moral role of government to Amarya Sen's (Pagliari, Bucciarelli, and Alessi 2011). The grounding of the Smithian theory of development in The Theory of Moral Sentiments and his willingness to deal with exceptional cases which did not easily fit his theory make Shudong Chen claim that "Smith needs China to understand his own theory then as much as we need him to understand China now in the current global context" (2013, p. 138). But if institutions and economic conditions grow symbiotically, if the development of society is holistic, imposing one in the absence of the other would make little sense. John Millar ridicules the possibility of successfully imposing complex commercial laws upon savages or barbarians who have little or no property in the hope of civilizing them. In addition, the speed of change that the Scots are describing is generational, which may not be ideal for today's policy recommendations (Paganelli 2012b).

What happens after the commercial stage is ambiguous. Adam Ferguson feared that the weakening of the martial spirit would bring about the conquest of the refined societies by barbarians 
(C. Smith 2014; McDaniel 2013). On the other hand, Adam Smith seems to be among the least concerned of the Scots about a potential conquest of the refined world by brute force of barbarians because of the superiority of the military revolution of the fire-arms in possession of commercial societies (Nohara 2010; cf. Hanley 2014). Smith, possibly a lone voice among his friends in the Poker Club, supports a standing army as opposed to a militia, attracting Ferguson's criticisms in their correspondence. But for Smith civilized commercial societies are specialized society, and specialization extends to the military too. If Adam Smith fears a regress or a decline of commercial societies, that would come from its deformation into a mercantile society, a society whose legislature has fallen prey of powerful interests of big merchants and manufacturers.

Another source of controversy, in $18^{\text {th }}$ century Scotland, regarding the future of commercial societies is how much improvement the presence of financial instruments brings. Adam Smith believes that banks and bank credit, and free banking in particular, are successful instruments of improvement. The economic boom of $18^{\text {th }}$ century Scotland is due in part to the innovation of banking. David Hume, on the other hand, sees banking and credit as one of the sources of destruction of commercial society. He is adamantly opposed to banking and paper money, with the reluctant exception of a 100 per cent reserve public bank (Paganelli 2014; see also Dimand 2013; for a general overview on the debate on money see Arnon 2011). Hume differs from Smith also with respect to public credit. Adam Smith believes that a large public debt, despite its potential dangers, is a sign of the soundness of a government and of its trustworthiness: Britain and Holland are the two countries with the largest public debts and they are two largest economies and the two most powerful countries. David Hume, on the other hand, believes that public debt will bring a country to its death and people who believe otherwise are simply deluded best-case thinkers (Paganelli 2012a; see also Hont 2005; and Berry 2013b).

The concept of improvement for the Scots links institutions and ideas at the macro as well as at the micro level. The Scottish literati provided powerful ideological justifications for change and commitments to the practical application of their ideas (on Smith's treatment of entrepreneurship see Aspromourgos 2014). Their interest in the relationship between men and the environment, how man can influence the environment and how the environment can influence men is present especially with agriculture, so much so that Fredrik Jonsson (2013) is willing to claim that environmentalism was born in $18^{\text {th }}$ century Scotland. 
Scottish agriculture proved a fertile ground where political economy and natural knowledge intertwine together: "The Scottish Improvers set out to improve Scotland literally from the ground up" (Bonnyman 2014, p. 5). And with the institutionalization of the ideology of improvement in bodies such as the Board of Agriculture, Scots would be able to export their ideas and affect even Imperial policies. "By the middle of the century, agricultural improvement itself was part of a much broader 'ideology of Improvement' that encompassed a whole range of activities, and attitudes, ranging from personal to political. In this respect, 'improvement' has to be considered as much a cultural concept as an economic one, one which embodies important moral, philosophic, and even aesthetic values.” (Bonnyman 2014, p. 7).

The Enlightenment "ideology of improvement" linked to agriculture is present at all levels of society (Smout 2012). While pastors in the most remote northern islands of the Highlands wrote public letters advocating agricultural improvements and identifying the local lords as sources of their resistance (Furuya 2011), in the rest of the country natural historians tried a large variety of experiments with a large variety of success rates (Jonsson 2013). For example, spade husbandry and potato cultivation were introduced and were immediate successes. There were attempts to introduce different kinds of sheep to develop sheep farming, the success of which was evident until 1790s. The Duke of Atholl grew rhubarb, from seeds brought from St. Petersburg, in the attempt to break into the Russian monopoly. Rhubarb was thought as a remedy against indigestion, a side-effect of luxury. He succeeded but eventually the production was moved to the possessions of the East India Company. To limit China's dominance in the tea market, John Hope tried, and failed, to produce Chinese tea in the Highlands of Scotland, while Joseph Banks planned to introduce Chinese tea cultivation in India, the success of which came in the $19^{\text {th }}$ century.

The strong relation between theory and practice is also exemplified in Adam Smith. While Friedrik Jonsson (2013) claims that Smith's concrete discussions tended to be uninteresting and concerned only with ideal intensive cereal production under the regime of mixed husbandry, so much so that "Smith treated it as a universal model of growth that could be extended across the British Empire from New Jersey to Bengal” (p. 49), Brian Bonnyman (2014) shows the influence of Smith on the concrete improvements of the Third Duke of Buccleuch's estate (see also Emerson 2013). Hiroyuki Furuya (Manuscript), indirectly, offers a possible explanation for Jonsson's and Bonnyman's different interpretation of Smith, reconciling the two: Smith's description of Scottish agriculture in the Wealth of Nations is not a picture of reality, but a fictitious ideal picture meant to 
evoke stoic ideals of sober virtues (on Smith's uses of real examples with added imaginative features see also Jean-Louis Peaucelle (2012)) .

\section{Religion}

The Enlightenment ideal expressed by Broadie ([2007] 2011) as of "think for yourself, (but not by yourself)" has at least one additional implication: the understanding of the role of a deity.

“Think for yourself” implies questioning the traditional sources of authority, such as religion. The Scots do not reject religion per se. Several literati were ministers of the church (e.g. John Walker, Alexander Gerard, Hugh Blair, as well as William Robertson and Adam Ferguson). They subjected the teaching of the church to critical and scientific examination. The teachings of a revealed religion are accepted when verified and in concordance with the teaching of science. Natural scientists believe in the Creator of the Universe because they see in the formidable intricacy of order of nature proof of a divine creator. The more knowledge about the creation the more one would be able to appreciate its creator (Wilson 2009; Jonsson 2013). James Hutton, John Walker, and Colin MacLaurin are striking examples of the lack of tension between science and religion in $18^{\text {th }}$ century Scotland.

The histories of religion that emerge in the Scottish Enlightenment are natural histories of religion, which means that religion is a subject suitable for experimental investigation. The Scots approach religion no differently than property so that the natural history of religion is similar in nature to the natural history of property (Berry 2013a), or as Mark Collier (2014) asks while describing Hume's analysis: "How did the flora and fauna of religion come to populate the world?" (p. 665). And Hume's analysis of the psychological mechanisms which generate belief in the supernatural, such as our illusion of control, seem to receive support from recent work on psychological responses to uncertainty coming from cognitive science of religion (Collier 2014).

The description of a providential order of nature is therefore an ambiguous presentation since it can foster interpretations supporting both a divine presence and divine absence. While Hutcheson has an explicit religious position and Hume an explicit non-religious position, Smith's position is ambiguous and debatable. So Geoff Cockfield, Ann Firth and John Laurent (2007) collect a series of essays showing the religious side of Adam Smith, while Gavin Kennedy (2011) shows that the 
religious appearance of Smith was due to his love to his religious mother but disappears from his published work as soon as his mother dies (on Smith and religion see also: Oslington 2011; Yang 2012) .

\section{Who is in the office?}

The ability of the Scots to dialogue with us today engages them in discussions not directly present in their time. Some of these discussions are more successful than others, nevertheless they are frequent and on a variety of topics.

Several Scots were influential and involved in the politics of the time. And that influence and involvement is discernible today too. It is frequent to see Adam Smith's name, in particular, associated with some political and ideological positions, regardless of whether Smith himself would actually hold those positions. So much is the textual violence that there are calls to go back to a reading of Smith as free as possible from an explicit imposition of today's political views. For example, Warren Samuels (2011) worked through a monumental research project to see how the Smithian concept of invisible hand is used and what Smith may mean by it. Adam Smith may have had a political agenda himself (Perelman 2010), yet Craig Smith (2013a) claims that Adam Smith should not be claimed by either today's right or today's left as the political spectrum of left and right in the context in which Smith lived and ours do not match. David Hardwick and Leslie Marsh (2014) wish to use Smith's understanding of complexity, order, and division of labor in the medical school in which they work. So they brought together a group of different experts to explain what Smith said, seeking to understand Adam Smith untangled from any political view imposed on him. Jerry Evensky (forthcoming) seems to write against writers imposing their own political ideas on Smith and offers a representation of the narrative in The Wealth of Nations that allows Smith to speak for himself.

In the field of business ethics, there seems to be an increasing and sensitive attention to the limits of homo economicus and an appreciation of analyses in which morals interact with self-interest and profit seeking. Adam Smith is therefore an ideal interlocutor. So for example, in a remarkable analysis, Juile Whittaker (2011) shows how Adam Smith's analysis parallels Elinor Ostrom's in terms of the interaction of self-interest and concern for others in dealing with common pool resources. She argues that Adam Smith can help us understand the development of responsible investment 
practices as a modern example of endogenous institutional changes that promote social goals thanks to the interactions of competitive markets and social norms.

To Karin Brown (2013), responsible practices could also be promoted by following Smith's spectatorial analysis of moral development by generating more awareness of the moral conduct of corporations with calls for transparency and accountability. Self-interest is not (should not be) the sole motivation for businesses; businesses (should) see themselves as subjects of approval and disapproval of a real or impartial spectator and deserving praise and praiseworthiness. Consumers as well are (should be) motivated by both self-interest and the desire to merit the praise of external and internal spectators. So forgoing a cheaper price (or higher profits) for a more expensive (or less profitable) product which is produced with more environmental friendly methods is not an irrational choice, but rather a choice that the Smithian apparatus of social approbation and praiseworthiness easily explains.

Adam Smith may also help us bridge our understanding of sustainable agricultural and narrow market practices, since he can be presented as, yes, describing economic interests but also social wellbeing and a sort of stewardship toward land (James 2006). Similarly, Smith's holistic theory of knowledge is something that international business theory should strive to imitate: Smith's understanding of the decline in sympathy over distance, for example, can shed better light on international business problems such as the difficulty in building mutual trust in the growth of emerging-country multinationals (Buckley 2014).

To conclude, I hope to have shown that the picture of recent literature on Adam Smith and the Scottish Enlightenment seem to represent that the Enlightenment imperative: 'Think with others' remains valid even across generations. As our current disciplines evolved, the studies of Adam Smith and the other Scots evolve with them; as our disciplines move toward new directions, the studies of Adam Smith and the other Scots follow them. Smith and the Scots remain our interlocutors across generations. Adam Smith and the Scots are still our colleagues indeed: they may not be in the office but they are down the hall. 
Bibliography

Ahnert, Thomas and Susan Manning, eds. 2011. Character, Self, and Sociability in the Scottish Enlightenment. New York: Palgrave Macmillan.

Arnon, Arie. 2011. "David Hume and Classical Monetary Theory." Unpublished Manuscript.

Ashraf, Nava, Colin F. Camerer, and George Loewenstein. 2005. "Adam Smith, Behavioral Economist." Journal of Economic Perspectives 19 (3): 131-145.

Aspromourgos, Tony. 2014. "Entrepreneurship, Risk and Income Distribution in Adam Smith." European Journal of the History of Economic Thought 21 (1): 21-40.

2009. The Science of Wealth Adam Smith and the Framing of Political Economy. London and New York: Routledge.

—. 2010. "'Universal Opulence': Adam Smith on Technical Progress and Real Wages." European Journal of the History of Economic Thought 17 (5): 1169-1182.

Backhouse, Roger and Steven G. Medema. 2009a. "Defining Economics: The Long Road to Acceptance of the Robbins Definition." Economica 76: 805-820.

- 2009b. "Retrospectives: On the Definition of Economics < br / >." Journal of Economic Perspectives 23 (1): 221-33.

Bender, Keith A., Colin P. Green, and John S. Heywood. 2012. "Piece Rates and Workplace Injury: Does Survey Evidence Support Adam Smith?" Journal of Population Economics 25 (2): 569-590.

Berry, Christopher J. 2013a. The Idea of Commercial Society in the Scottish Enlightenment. Edinburgh, Scotland: Edinburgh University Press.

- 2013b. The Idea of Commercial Society in the Scottish Enlightenment. Edinburgh, Scotland: Edinburgh University Press.

Berry, Christopher J. 2012. "Adam Smith's "Science of Human Nature"." History of Political Economy 44 (3): 471-492.

—. 2010. "Adam Smith's Moral Economy." Kyoto Economic Review 79 (1): 2-15.

Berry, Christopher J., Maria Pia Paganelli, and Craig Smith, eds. 2013. The Oxford Handbook of Adam Smith. Oxford and New York: Oxford University Press.

Bonnyman, Brian. 2014. The Third Duke of Buccleauch and Adam Smith: Estate Management and Improvement in Enlightenment Scotland. Edinburgh: Edinburgh University Press.

Broadie, Alexander. [2007] 2011. Scottish Enlightenment. Edinburgh: Birlinn Limited. 
Broadie, Alexander. 2012. Agreeable Connexions: Scottish Enlightenment Links with France. Edinburgh: John Donald.

- 2006. The Cambridge Companion to the Scottish Enlightenment. Cambridge: Cambridge University Press.

Brown, Karin. 2013. "Adam Smith, Moral Motivation and Business Ethics." Ethics and Economics/Ethique Economique 10 (1): 84-94.

Brown, Vivienne. 1997. "'Mere Inventions of the Imagination': A Survey of Recent Literature on Adam Smith." Economics and Philosophy 13 (02): 281-312.

Buchan, James. 2003. Crowded with Genius: The Scottish Enlightenment: Edinburgh's Moment of the Mind. New York: HarperCollins.

Buckley, Peter J. 2014. "Adam Smith's Theory of Knowledge and International Business Theory and Practice." Journal of International Business Studies 45 (1): 102-109.

Chen, Shudong. 2013. "Understanding China's Economic Growth in Global Context through Adam Smith the Overlooked Moral Philosopher Behind the Overrated "Capitalist" Economist." International Journal of China Studies 4 (1): 129-165.

Cockfield, Geoff, Ann Firth, and John Laurent, eds. 2007. New Perspectives on Adam Smith's the Theory of Moral Sentiments. Cheltenham, UK; Northampton, MA: Edward Elgar.

Collier, Mark. 2011. "Hume’s Science of Emotions: Feeling Theory without Tears." Hume Studies 37 (1): 3-18.

—. 2010. "Hume's Theory of Moral Imagination." History of Philosophy Quarterly 27 (3): 255-273.

—. 2014. "The Natural Foundations of Religion." Philosophical Psychology 27 (5): 665-680.

Dimand, Robert W. 2013. "David Hume and Irving Fisher on the Quantity Theory of Money in the Long Run and the Short Run." European Journal of the History of Economic Thought 20 (2): 284-304.

Dow, Alexander and Sheila C. Dow, eds. 2006. A History of Scottish Economic Thought. London: Routledge.

Dow, Sheila. 2009. "Knowledge, Communication and the Scottish Enlightenment." Revue De Philosophie Economique/Review of Economic Philosophy 10 (2): 3-23.

Emerson, Roger L. 2013. An Enlightened Duke: The Life of Archibald Campbell (1692-1761), Earl of Ilay, 3rd Duke of Argyll. Kilkerran, Scotland: Humming Earth.

Evensky, Jerry. 2005. Adam Smith's Moral Philosophy. Cambridge and New York: Cambridge University Press. 
forthcoming. Adam Smith's Wealth of Nations: A Reader's Guide. Cambridge and New York: Cambridge University Press.

Fleischacker, Samuel. 2011a. "True to Ourselves? - Adam Smith on Self-Deceit." Adam Smith Review 6: 75-92.

Fleischacker, Samuel. 2011b. "Adam Smith and Cultural Relativism." Erasmus Journal for Philosophy and Economics 4 (2): 20-41.

Forman-Barzilai, Fonna. 2010. Adam Smith and the Circles of Sympathy Cosmopolitanism and Moral Theory. Cambridge and New York: Cambridge University Press.

Furuya, Hiroyuki. Manuscript. "Adam Smith and His Stoic Characterisation of the MerchantLandowner in The Wealth of Nations." .

- 2011. "Working the Peripheral into the Picture: The Case of Thomas Hepburn in Eighteenth-Century Orkney." The European Journal of the History of Economic Thought 18 (5): 697714.

Gabrinetti, Paul A. and Şule Özler. 2014. "Defenses and Morality: Adam Smith, Sigmund Freud, and Contemporary Psychoanalysis." The Psychoanalytic Review 101 (5): 735-765.

Garrett, Aaron. 2006. "Introduction." In The Origin of the Distinction of Ranks, Or, an Inquiry into the Circumstances which Give Rise to Influence and Authority, in the Different Members of Society by John Millar. Indianapolis: Liberty Fund.

Garrett, Aaron and James Harris. Forthcoming. Scottish Philosophy in the Eighteenth Century Oxford University Press.

Gintis, Herbert, Samuel Bowles, Robert Boyd, and Ernst Fehr, eds. 2005. Moral Sentiments and Material Interests the Foundations of Cooperation in Economic Life. Cambridge, Mass.: MIT Press.

Haakonssen, Knud, ed. 2006. The Cambridge Companion to Adam Smith. Cambridge: Cambridge University Press.

Hanley, Ryan Patrick. 2014. "The "Wisdom of the State": Adam Smith on China and Tartary." American Political Science Review 108 (2): 371-382.

- 2009. Adam Smith and the Character of Virtue New York: Cambridge University Press, 2009.

Hardwick, David and Leslie Marsh, eds. 2014. Propriety and Prosperity: New Studies on the Philosophy of Adam Smith. New York: Palgrave Macmillan.

Harris, James. Forthcoming. An Intellectual Biography of David Hume. Cambridge: Cambridge University Press. 
Herzog, Lisa. 2013. Inventing the Market: Smith, Hegel, and Political Theory. Oxford: Oxford University Press.

Hont, Istvan. 2005. Jealousy of Trade: International Competition and the Nation State in Historical Perspective. Cambridge, Mass.: Belknap Press of Harvard University Press.

Iacoboni, Marco. 2008. Mirroring People: The New Science of how we Connect with Others. New York: Farrar, Straus, Giroux.

James, Harvey S.,Jr. 2006. "Sustainable Agriculture and Free Market Economics: Finding Common Ground in Adam Smith." Agriculture and Human Values 23 (4): 427-438.

Jaworski, Taylor, Vernon L. Smith, and Bart J. Wilson. 2010. "Discovering Economics in the Classroom with Experimental Economics and the Scottish Enlightenment." International Review of Economics Education 9 (2): 10-33.

Jonsson, Fredrik Albritton. 2013. Enlightenment's Frontier: The Scottish Highlands and the Origins of Environmentalism. New Haven and London: Yale University Press.

Kennedy, Gavin. 2011. "The Hidden Adam Smith in His Alleged Theology." Journal of the History of Economic Thought 33 (3): 385-402.

Khalil, Elias L. 2010. "Adam Smith's Concept of Self-Command as a Solution to Dynamic Inconsistency and the Commitment Problem." Economic Inquiry 48 (1): 177-191.

- 2011. "Mirror Neurons Paradox: How Far is Understanding from Mimicking?" Journal of Economic Behavior and Organization 77 (1): 66-75.

_ 2009. "Self-Deceit and Self-Serving Bias: Adam Smith on 'General Rules'." Journal of Institutional Economics 5 (2): 251-254.

Kiesling, L. Lynne. 2012. "Mirror Neuron Research and Adam Smith's Concept of Sympathy: Three Points of Correspondence." Review of Austrian Economics 25 (4): 299-313.

Kim, Kwangsu. 2014. "Adam Smith's and Douglass North's Multidisciplinary Approach to Economic Development." American Journal of Economics and Sociology 73 (1): 3-31.

Konow, James. 2012. "Adam Smith and the Modern Science of Ethics." Economics and Philosophy 28 (3): 333-362.

- 2000. "Fair Shares: Accountability and Cognitive Dissonance in Allocation Decisions. ." American Economic Review 90: 1072-92.

Martin, Christopher. Forthcoming. "Equity, Besides: Adam Smith and the Utility of Poverty." Journal of the History of Economic Thought. 
McDaniel, Iain. 2013. Adam Ferguson in the Scottish Enlightenment the Roman Past and Europe's Future. Cambridge, Mass.: Harvard University Press.

McKenna, Stephen J. 2006. Adam Smith: The Rhetoric of Propriety. Albany: State University of New York Press.

Mizuta, Hiroshi. 2000. Adam Smith's Library: A Catalogue. New York and Oxford: Oxford University Press.

Montes, Leonidas. 2008a. "Adam Smith as an Eclectic Stoic." Adam Smith Review 4: 30-56.

- 2004. Adam Smith in Context: A Critical Reassessment of some Central Components of His Thought. New York: Palgrave Macmillan.

- 2008b. "Newton's Real Influence on Adam Smith and its Context." Cambridge Journal of Economics 32 (4): 555-576.

Montes, Leonidas and Eric Schliesser, eds. 2006. New Voices on Adam Smith. New York: Routledge.

Nagao, Shinichi. 2007. Politics and Society in Scottish Thought. Exeter, UK and Charlottesville, Va.: Imprint Academic.

Nohara, Shinji. 2010. "Adam Smith on the Cyclicity of the Rise and Fall of Civilization." Kyoto Economic Review 79 (1): 77-89.

Norton, David Fate, ed. 2009. The Cambridge Companion to Hume. Cambridge: Cambridge University Press.

Oslington, Paul, ed. 2011. Adam Smith as Theologian. New York: Routledge.

Özler, Şule. 2012. "Adam Smith and Dependency." Psychoanalytic Review 99 (3): 333-358.

Özler, Şule and Paul Gabrinetti. forthcoming. "A Known World: An Analysis of Defenses in Adam Smith's the Theory of Moral Sentiments." Adam Smith Review 8.

Paganelli, Maria Pia. 2013. "Commercial Relations: From Adam Smith to Field Experiments." In The Oxford Handbook of Adam Smith, edited by Christopher J. Berry, Maria Pia Paganelli and Craig Smith, 333-352. Oxford, New York: Oxford University Press.

—. 2014. "David Hume on Banking and Hoarding." Southern Economic Journal 80 (4): 968-980.

—. 2012a. "David Hume on Public Credit." History of Economic Ideas 20 (1): 31-43.

- 2012b. "Economies in Transition and in Development: A Possible Warning from Adam Smith." European Journal of the History of Economic Thought 19 (2): 149-163. 
- 2010. "The Moralizing Role of Distance in Adam Smith: The Theory of Moral Sentiments as Possible Praise of Commerce." History of Political Economy 42 (3): 425-441.

- 2011. "The Same Face of the Two Smiths: Adam Smith and Vernon Smith." Journal of Economic Behavior and Organization 78 (3): 246-255.

Pagliari, Carmen, Edgardo Bucciarelli, and Michele Alessi. 2011. "From Adam Smith to Amartya Sen: Global Market as a Possible Instrument to Promote Socio-Economic Development." Investigacion Economica 70 (278): 129-156.

Peach, Terry. 2014. "Adam Smith's "Optimistic Deism", the Invisible Hand of Providence, and the Unhappiness of Nations." History of Political Economy 46 (1): 55-83.

Peaucelle, Jean-Louis. 2012. "Rethoric and Logic in Smith's Description of the Division of Labor." European Journal of the History of Economic Thought 19 (3): 385-408.

Perelman, Michael. 2010. "Adam Smith: Class, Labor, and the Industrial Revolution." Journal of Economic Behavior and Organization 76 (3): 481-496.

- 2011. The Invisible Handcuffs of Capitalism: How Market Tyranny Stifles the Economy by Stunting Workers. New York: Monthly Review Press.

Phillipson, Nicholas T. 2010. Adam Smith: An Enlightened Life. New Haven and London: Yale University Press.

Raphael, David Daiches. 2007. The Impartial Spectator: Adam Smith's Moral Philosophy. Oxford, New York: Oxford University Press.

Rasmussen, Dennis C. 2006. "Does 'Bettering our Condition' really make Us Better Off? Adam Smith on Progress and Happiness." American Political Science Review 100 (3): 309-318.

Recktenwald, Horst Claus. 1978. "An Adam Smith Renaissance Anno 1976? the Bicentenary Output-A Reappraisal of His Scholarship." Journal of Economic Literature 16 (1): 56-83.

Ross, Ian Simpson. [1995] 2010. The Life of Adam Smith. Oxford and New York: Oxford University Press.

Rutherford, Donald. 2012. In the Shadow of Adam Smith: Founders of Scottish Economics, 1700-1900. New York: Palgrave Macmillan.

Salter, John. 2012. "Adam Smith on Justice and the Needs of the Poor." Journal of the History of Economic Thought 34 (4): 559-575.

Samuels, Warren J. 2007. "Adam Smith's History of Astronomy Argument: How Broadly does it Apply? and Where do Propositions which 'Sooth the Imagination' Come from?" History of Economic Ideas 15 (2): 53-78. 
-2011. Erasing the Invisible Hand: Essays on an Elusive and Misused Concept in Economics. New York: Cambridge University Press.

Schliesser, Eric. 2013. "The Piacular, Or on Seeing Oneself as a Moral Cause in Adam Smith." In Contemporary Perspective in Early Modern Philosophy, edited by Lenz, Martin, Waldow, Anik, 159177. Dordrecht, Heidelberg, New York and London: Springer.

- 2011. "Reading Adam Smith After Darwin: On the Evolution of Propensities, Institutions, and Sentiments." Journal of Economic Behavior and Organization 77 (1): 14-22.

—. 2014. "Toland and Adam Smith's Posthumous Works." Diametros 40: 115-125.

Schumacher, Reinhard. 2012. "Adam Smith's Theory of Absolute Advantage and the use of Doxography in the History of Economics." Erasmus Journal for Philosophy and Economics 5 (2): $54-$ 80 .

Sebastiani, Silvia. 2013. The Scottish Enlightenment: Race, Gender, and the Limits of Progress. New York: Palgrave Macmillar.

Sen, Amartya. 2010. The Idea of Justice. London: Penguin.

Smith, Craig. 2013a. "Adam Smith: Left Or Right?" Political Studies 61 (4): 784-798.

- 2014. "'We have Mingled Politeness with the use of the Sword': Nature and Civilisation in Adam Ferguson's Philosophy of War." European Legacy 19 (1): 1-15.

Smith, Vernon L. 2013b. "Adam Smith: From Propriety and Sentiments to Property and Wealth." Forum for Social Economics 42 (4): 283-297.

- 2008. Rationality in Economics: Constructivist and Ecological Forms. Cambridge and New York: Cambridge University Press.

Smith, Vernon L. and Bart J. Wilson. 2014. "Fair and Impartial Spectators in Experimental Economic Behavior." Review of Behavioral Economics 1 (1): 1-26.

Smout, T. C. 2012. "A New Look at the Scottish Improvers." The Scottish Historical Review 91 (1): 125149.

Tribe, Keith. 1999. "Adam Smith: Critical Theorist?<br />." Journal of Economic Literature 37 (2): 609632.

Turnbull, George. [1740] 2005. The Principles of Moral and Christian Philosophy. Indianapolis: Liberty Fund.

Wagner, Richard E. 2014. "Entangled Political Economy: A Keynote Address." In Entangled Political Economy, edited by Roger Koppl and Steven Horwitz. Advances in Austrian Economics ed. Vol. 18, 15-36. Bingley, UK: Emerald. 
- 2010. Mind, Society, and Human Action: Time and Knowledge in a Theory of Social Economy. . London: Routledge.

Waterman, A. M. C. 2012. "Adam Smith and Malthus on High Wages." European Journal of the History of Economic Thought 19 (3): 409-429.

Waterman, A. M. C. 2014. "Is there another, quite Different, "Adam Smith Problem”?" Journal of the History of Economic Thought 36 (04): 401-420.

Weinstein, Jack Russell. 2013. Adam Smith's Pluralism: Rationality, Education, and the Moral Sentiments. New Haven: Yale University Press.

- 2006. "Sympathy, Difference, and Education: Social Unity in the Work of Adam Smith." Economics and Philosophy 22 (1): 79-111.

Whittaker, Julie. 2011. "The Evolution of Environmentally Responsible Investment: An Adam Smith Perspective." Ecological Economics 71 (1): 33-41.

Wight, Jonathan B. 2009. "Adam Smith on Instincts, Affection, and Informal Learning: Proximate Mechanisms in Multilevel Selection." Review of Social Economy 67 (1): 95-113.

Wilson, David B. 2009. Seeking Nature's Logic: Natural Philosophy in the Scottish Enlightenment. University Park, Pa.: Pennsylvania State University Press.

Witztum, Amos. 2013. "Adam Smith and the Need of the Poor: A Rejoinder." Journal of the History of Economic Thought 35 (2): 257-262.

- 2010. "Interdependence, the Invisible Hand, and Equilibrium in Adam Smith." History of Political Economy 42 (1): 155-192.

- 2005. "Social Circumstances and Rationality: Some Lessons from Adam Smith Why we may Not all be Equally Sovereign." American Journal of Economics and Sociology 64 (4): 1025-1047.

Witztum, Amos and Jeffrey T. Young. 2006. "The Neglected Agent: Justice, Power, and Distribution in Adam Smith." History of Political Economy 38 (3): 437-471.

Yang, Yong-Sun. 2012. Economies of Salvation Adam Smith and Hegel. Oxford; New York: Peter Lang.

Young, Jeffrey T., ed. 2009. Elgar Companion to Adam Smith. Cheltenham, UK: Edward Elgar Publishing.

Zak, Paul J., ed. 2008. Moral Markets: The Critical Role of V alues in the Economy. Princeton: Princeton University Press.

Zak, Paul J. 2012. The Moral Molecule: The Source of Love and Prosperity. New York: Dutton. 
Appendix

Some of the Scottish literati:

John Anderson (1726-1796). Professor of Oriental Languages and Natural Philosophy. University of Glasgow.

James Beattie (1735-1803). Poet and professor of Moral Philosophy. University of Aberdeen.

Joseph Black (1728-1799). Professor of Anatomy and Chemistry. University of Glasgow and Professor of Medicine and Chemistry. University of Edinburgh. [Executor of Adam Smith]

Hugh Blair (1718-1800). Chair of Rhetoric and Belles Lettres. University of Edinburgh. Minister of the Church of Scotland.

George Campbell (1719-1796). Rhetoric. Divinity. Principal of Marischal College at University of Aberdeen. Minister.

William Cullen (1710-1790). Chemistry. Agriculture. Professor at Glasgow University and the Edinburgh Medical School. First Physician to the King in Scotland, one of the prime movers in obtaining a royal charter for the Philosophical Society of Edinburgh.

Archibald Davidson (1732-1803). Doctor of Divinity. Principal of the University of Glasgow.

Robert Davidson (son of Archibald). Regius Professor of Civil Law. University of Glasgow.

Sir Alexander Dick (1703-1785). Physician. President of the College of Physicians of Edinburgh.

Dr. Robert Dick (d. 1757). Professor of natural philosophy. University of Glasgow. Introduced Watt to Black.

James Dunbar (1742-1798). Professor of Moral Philosophy and regent of King's College of the University of Aberdeen.

Lord Dundas (1742-1811). Advocate. First secretary of State for War. Edinburgh.

Adam Ferguson (1723-1816). Chaplain of the 43rd regiment (Highland). Professor of Natural Philosophy and chair of Pneumatics and Moral Philosophy. University of Edinburgh. 
Alexander Gerard (1728-1795). Minister. Professor of Natural Philosophy and of Divinity at Marischal College of the University of Aberdeen and Professor of Divinity at the University and King's College of Aberdeen.

David Gregory (1659-1708). Astronomy (Newton). Professor of Mathematics. University of Edinburgh.

John Gregory (1724-1773). Physician. Professor of Mathematics and Natural and Moral Philosophy. King's college of the University of Aberdeen and Professor of Medicine at the University of Edinburgh.

Lord Kames (1696-1782). Advocate. Edinburgh.

John Keill (1671-1721). Professor of Astronomy. Oxford.

John Hope (1725-1786). King's Botanist. Professor of Medicine. University of Edinburgh.

John Hunter (1728-1793). Surgeon. London

James Hutton (1726-1797). Physician. Geology, chemistry, agriculture. Edinburgh. [Executor of Adam Smith]

William Leechman (1706-1785). Minister. Professor of Divinity at the University of Glasgow.

Henry Mackenzie (1745-1831) Lawyer. Novelist. Edinburgh.

Colin Maclaurin (1698-1746). Astronomy. Professor of Mathematics. Marishal College of the University of Aberdeen.

John Millar (1735-1801). Regius Professor of Civil Law at the University of Glasgow.

John Playfair (1748-1819). Professor of Natural Philosophy at the University of Edinburgh.

John Pringle (1707-1782). Physician. Professor of Moral Philosophy at Edinburgh University.

Allan Ramsay (1713-1784). Painter. Edinburgh.

Thomas Reid (1710-1796). Minister. Professor of moral Philosophy at the University and King's College of Aberdeen and at the University of Glasgow.

William Robertson (1721-1792). Minister. History. Principal of the University of Edinburgh. 
John Robison (1739-1805). Physicist and mathematician. Professor of Philosophy at the University of Edinburgh. Inventor of the siren and worked with Watt on steam car.

Sir John Sinclair (1754-1835). Statistics. Agriculture. Edinburgh.

John Stevenson (1695-1775). Professor of Logic and Rhetoric at University of Edinburgh.

Dugald Stewart (1753-1828). Professor of Mathematics and chair of Moral Philosophy at the University of Edinburgh.

George Turnbull (1698-1748). Clergyman. Theologian. Regent at Marischal College of the University of Aberdeen.

Robert Wallace (1697-1771). Minister. Population. Edinburgh.

James Watt (1736-1819). Inventor of the steam engine. Glasgow.

John Walker (1731-1803). Minister. Botany. Regius Professor of Natural history at the University of Edinburgh.

Alexander Wilson (1714-1786). Regius Professor of Practical Astronomy at the University of Glasgow.

Among the many. 
Appendix

Just to give a sense of the size of the literature:

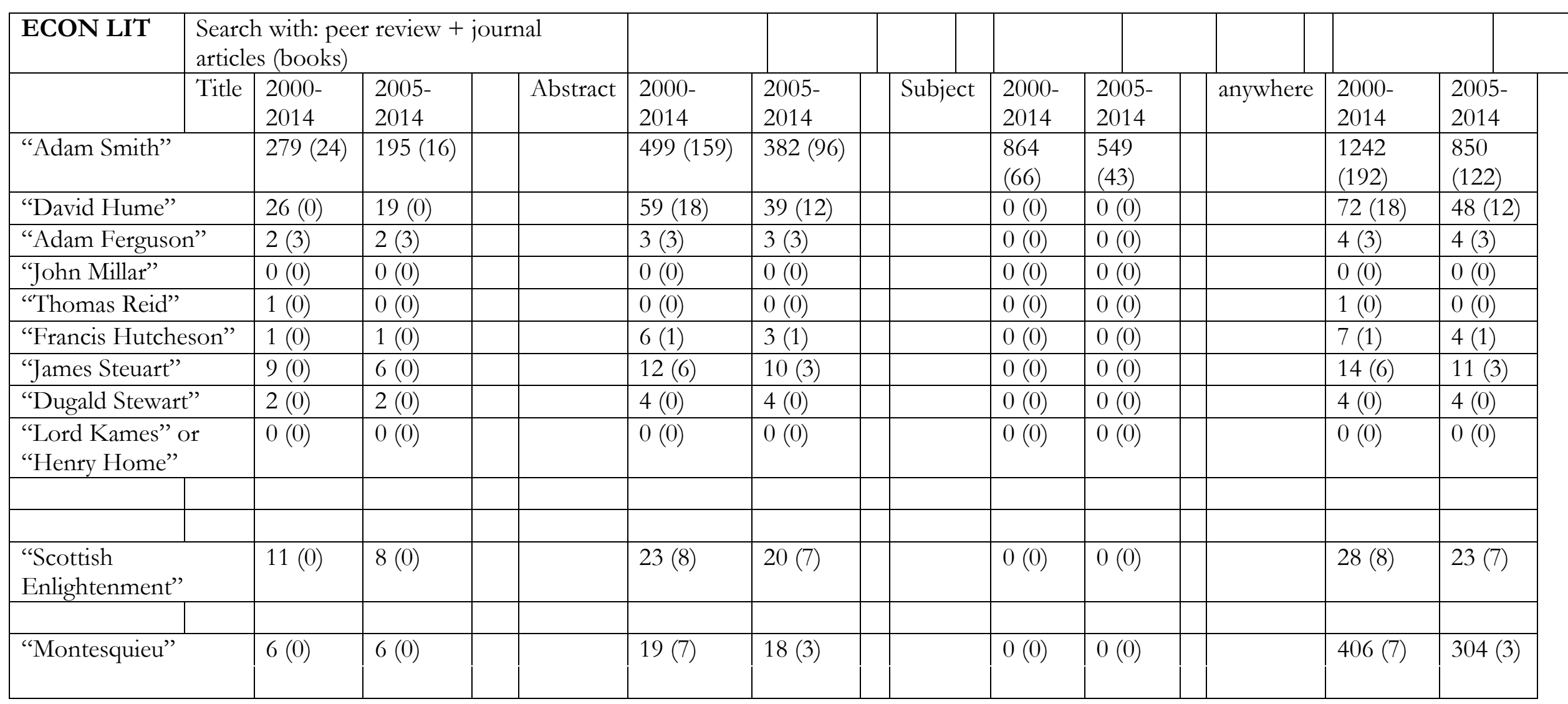




\begin{tabular}{|c|c|c|c|c|c|c|c|c|c|c|c|c|}
\hline \multirow[t]{2}{*}{ PROQUEST } & \multicolumn{4}{|c|}{$\begin{array}{l}\text { scholarly journal+article and essay+peer } \\
\text { reviewed (books) }\end{array}$} & \multirow[b]{2}{*}{$\begin{array}{l}2000- \\
2014\end{array}$} & \multirow[b]{2}{*}{$\begin{array}{l}2005- \\
2014\end{array}$} & \multirow[b]{2}{*}{ Subject } & \multirow[b]{2}{*}{$\begin{array}{l}2000- \\
2014\end{array}$} & \multirow[b]{2}{*}{$\begin{array}{l}2005- \\
2014\end{array}$} & \multirow[b]{2}{*}{ anywhere } & \multirow[b]{2}{*}{$\begin{array}{l}2000- \\
2014\end{array}$} & \multirow[b]{2}{*}{$\begin{array}{l}2005- \\
2014\end{array}$} \\
\hline & Title & $\begin{array}{l}2000- \\
2014\end{array}$ & $\begin{array}{l}2005- \\
2014\end{array}$ & Abstract & & & & & & & & \\
\hline \multicolumn{2}{|l|}{ "Adam Smith" } & $\begin{array}{l}861 \\
(186)\end{array}$ & $\begin{array}{l}571 \\
(114)\end{array}$ & & $\begin{array}{l}1870 \\
(240)\end{array}$ & $\begin{array}{l}1419 \\
(161)\end{array}$ & & $\begin{array}{l}951 \\
(537)\end{array}$ & $\begin{array}{l}592 \\
(279)\end{array}$ & & $\begin{array}{l}10499 \\
(936)\end{array}$ & $\begin{array}{l}7360 \\
(576)\end{array}$ \\
\hline \multicolumn{2}{|l|}{ "David Hume" } & $151(22)$ & $85(17)$ & & $549(69)$ & $370(47)$ & & $59(7)$ & $11(0)$ & & $\begin{array}{l}3438 \\
(95)\end{array}$ & $\begin{array}{l}2390 \\
(60)\end{array}$ \\
\hline \multicolumn{2}{|c|}{ "Adam Ferguson" } & $17(5)$ & $15(5)$ & & $25(10)$ & $21(7)$ & & $6(0)$ & $5(0)$ & & $343(10)$ & $259(7)$ \\
\hline \multicolumn{2}{|l|}{ "John Millar" } & $0(0)$ & $0(0)$ & & $3(2)$ & $3(1)$ & & $0(0)$ & $0(0)$ & & $97(4)$ & $70(2)$ \\
\hline \multicolumn{2}{|c|}{ "Thomas Reid" } & $45(13)$ & $27(4)$ & & $92(16)$ & $56(5)$ & & $16(1)$ & $13(0)$ & & $533(23)$ & $360(8)$ \\
\hline \multicolumn{2}{|c|}{ "Francis Hutcheson" } & $7(3)$ & $5(2)$ & & $45(4)$ & $37(2)$ & & $3(0)$ & $0(0)$ & & $356(6)$ & $198(4)$ \\
\hline \multicolumn{2}{|c|}{ "James Steuart" } & $11(4)$ & $8(3)$ & & $19(8)$ & $14(4)$ & & $1(0)$ & $0(0)$ & & $88(12)$ & $61(7)$ \\
\hline \multicolumn{2}{|l|}{ "Dugald Stewart" } & $10(0)$ & $9(1)$ & & $18(4)$ & $18(3)$ & & $9(0)$ & $9(0)$ & & $207(5)$ & $171(4)$ \\
\hline \multicolumn{2}{|l|}{$\begin{array}{l}\text { "Lord Kames" or } \\
\text { "Henry Home" }\end{array}$} & $\begin{array}{l}1 \text { or } 0(0 \\
\text { or } 0)\end{array}$ & $\begin{array}{l}0 \text { or } 0(0 \\
\text { or } 0)\end{array}$ & & $\begin{array}{l}11 \text { or } 9(0 \\
\text { or } 0)\end{array}$ & $\begin{array}{l}7 \text { or } 7(0 \\
\text { or } 0)\end{array}$ & & $\begin{array}{l}7 \text { or } 1 \\
(0 \text { or } \\
0) \\
\end{array}$ & $\begin{array}{l}5 \text { or } 0 \\
(0 \text { or } \\
0) \\
\end{array}$ & & $\begin{array}{l}121 \text { or } \\
92(0 \text { or } \\
0)\end{array}$ & $\begin{array}{l}88 \text { or } \\
71(2 \\
\text { or } 0) \\
\end{array}$ \\
\hline & & & & & & & & & & & & \\
\hline \multicolumn{2}{|l|}{$\begin{array}{l}\text { "Scottish } \\
\text { Enlightenment" }\end{array}$} & $39(11)$ & $27(8)$ & & $117(19)$ & $86(15)$ & & $10(0)$ & $10(0)$ & & $978(27)$ & $\begin{array}{l}632 \\
(21)\end{array}$ \\
\hline & & & & & & & & & & & & \\
\hline \multicolumn{2}{|l|}{ "Montesquieu" } & $118(31)$ & 80 (24) & & $321(55)$ & $217(41)$ & & $\begin{array}{l}162 \\
(29)\end{array}$ & $95(24)$ & & $\begin{array}{l}3228 \\
(103)\end{array}$ & $\begin{array}{l}2396 \\
(64)\end{array}$ \\
\hline
\end{tabular}




\begin{tabular}{|l|l|l|l|l|l|l|l|l|l|l|l|}
\hline JSTOR & \multicolumn{2}{l}{ Economics +articles (in } \\
books)
\end{tabular}




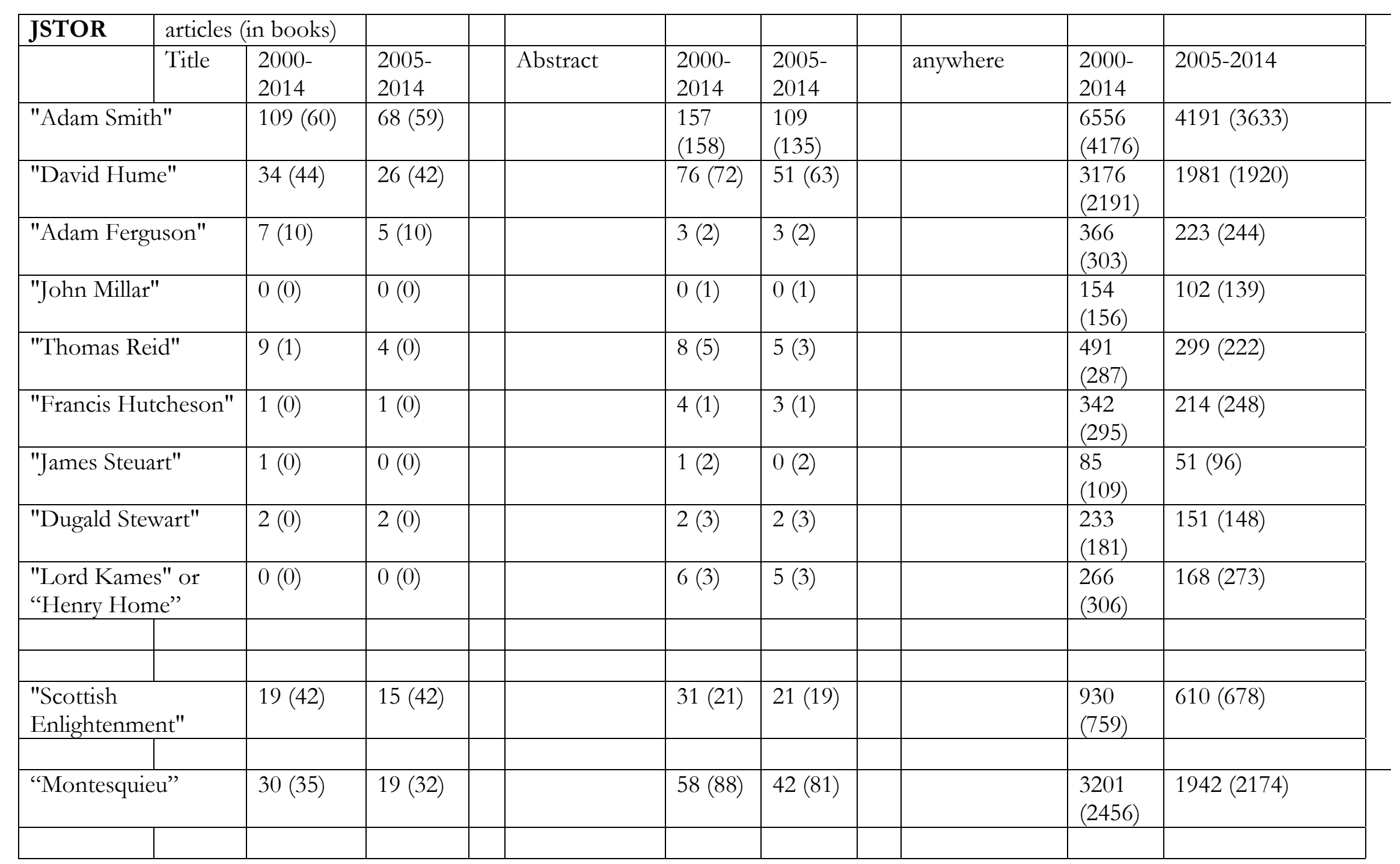




\begin{tabular}{|c|c|c|c|c|c|c|c|c|c|}
\hline \multirow[t]{2}{*}{ HOPE } & \multicolumn{2}{|c|}{ articles + reviews } & \multirow[b]{2}{*}{$\begin{array}{l}2005- \\
2014\end{array}$} & \multirow[b]{2}{*}{$\begin{array}{l}\text { Title }+ \\
\text { Abstract }\end{array}$} & \multirow[b]{2}{*}{$\begin{array}{l}2000- \\
2014\end{array}$} & \multirow[b]{2}{*}{$\begin{array}{l}2005- \\
2014\end{array}$} & \multirow[b]{2}{*}{$\begin{array}{l}\text { Title + } \\
\text { Abstract } \\
+ \text { Text }\end{array}$} & \multirow[b]{2}{*}{$\begin{array}{l}2000- \\
2014\end{array}$} & \multirow[b]{2}{*}{$\begin{array}{l}2005- \\
2014\end{array}$} \\
\hline & Title & $\begin{array}{l}2000- \\
2014\end{array}$ & & & & & & & \\
\hline \multicolumn{2}{|c|}{ "Adam Smith" } & 50 & 36 & & 56 & 42 & & 493 & 334 \\
\hline \multicolumn{2}{|c|}{ "David Hume" } & 7 & 1 & & 8 & 2 & & 155 & 108 \\
\hline \multicolumn{2}{|c|}{ "Adam Ferguson" } & 0 & 0 & & 0 & 0 & & 28 & 22 \\
\hline \multicolumn{2}{|c|}{ "John Millar" } & 0 & 0 & & 0 & 0 & & 7 & 2 \\
\hline \multicolumn{2}{|c|}{ "Thomas Reid" } & 1 & 0 & & 1 & 0 & & 16 & 8 \\
\hline \multicolumn{2}{|c|}{$\begin{array}{l}\text { "Francis } \\
\text { Hutcheson" }\end{array}$} & 0 & 0 & & 1 & 1 & & 55 & 44 \\
\hline \multicolumn{2}{|c|}{ "James Steuart" } & 1 & 0 & & 2 & 1 & & 43 & 33 \\
\hline \multicolumn{2}{|c|}{ "Dugald Stewart" } & 1 & 1 & & 3 & 3 & & 31 & 21 \\
\hline \multicolumn{2}{|c|}{$\begin{array}{l}\text { "Lord Kames" or } \\
\text { "Henry Home" }\end{array}$} & 0 & 0 & & 0 & 0 & & 7 or 4 & 2 or 2 \\
\hline & & & & & & & & & \\
\hline \multicolumn{2}{|c|}{$\begin{array}{l}\text { "Scottish } \\
\text { Enlightenment" }\end{array}$} & 1 & 1 & & 1 & 1 & & 103 & 79 \\
\hline \multicolumn{2}{|c|}{ "Montesquieu" } & 0 & 0 & & 0 & 0 & & 48 & 39 \\
\hline
\end{tabular}




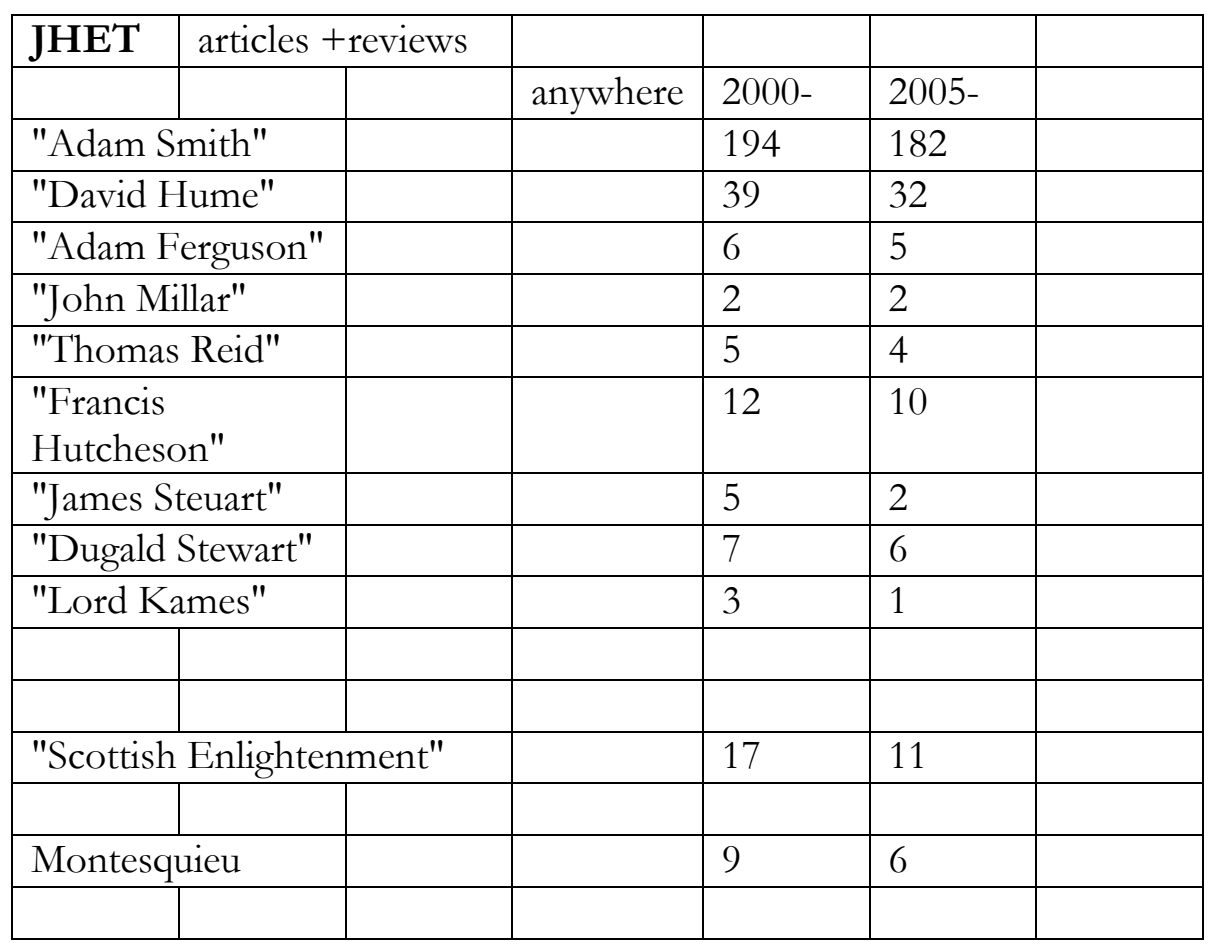




\begin{tabular}{|l|l|l|l|l|}
\hline BOOKS & (worldcat) & & \\
\hline Title & In English & $2000-2014$ & $2005-2014$ & $2010-2014$ \\
\hline "Adam Smith" & 451 & 313 & 173 \\
\hline "David Hume" & 309 & 227 & 119 \\
\hline "Adam Ferguson" & 34 & 26 & 13 \\
\hline "John Millar" & 8 & 3 & 2 \\
\hline "Thomas Reid" & 80 & 47 & 26 \\
\hline "Francis Hutcheson" & 21 & 13 & 6 \\
\hline "James Steuart" & 7 & 1 & 1 \\
\hline "Dugald Stewart" & 15 & 11 & 7 \\
\hline "Lord Kames" & 14 & 6 & 3 \\
\hline \multicolumn{2}{|l|}{} & & & \\
\hline \multicolumn{2}{|l|}{} & 159 & 101 & 46 \\
\hline \multicolumn{2}{|l|}{} & 176 & & 69 \\
\hline
\end{tabular}

